\title{
Bricks and mortar of the epidermal barrier
}

\author{
Zoltan Nemes ${ }^{1}$ and Peter M. Steinert ${ }^{1,2}$ \\ 1 Laboratory of Skin Biology, National Institute of Arthritis and \\ Musculoskeletal and Skin Diseases, National Institutes of Health, \\ Maryland 20892-2752, U.S.A. \\ 2 Corresponding author: Telephone, 301-496-1578; FAX, 301-402-2886; e-mail \\ pemast@helix.nih.gov \\ Accepted 2 March 1999
}

Abbreviations: CE, cornified cell envelope; KIF, keratin intermediate filaments; SPR, small proline rich protein; TGase, transglutaminase

\begin{abstract}
A specialized tissue type, the keratinizing epithelium, protects terrestrial mammals from water loss and noxious physical, chemical and mechanical insults. This barrier between the body and the environment is constantly maintained by reproduction of inner living epidermal keratinocytes which undergo a process of terminal differentiation and then migrate to the surface as interlocking layers of dead stratum corneum cells. These cells provide the bulwark of mechanical and chemical protection, and together with their intercellular lipid surroundings, confer water-impermeability. Much of this barrier function is provided by the cornified cell envelope (CE), an extremely tough protein/lipid polymer structure formed just below the cytoplasmic membrane and subsequently resides on the exterior of the dead cornified cells. It consists of two parts: a protein envelope and a lipid envelope. The protein envelope is thought to contribute to the biomechanical properties of the CE as a result of cross-linking of specialized CE structural proteins by both disulfide bonds and $\boldsymbol{N}^{\varepsilon}$-( $\gamma$-glutamyl)lysine isopeptide bonds formed by transglutaminases. Some of the structural proteins involved include involucrin, loricrin, small proline rich proteins, keratin intermediate filaments, elafin, cystatin A, and desmosomal proteins. The lipid envelope is located on the exterior of and covalently attached by ester bonds to the protein envelope and consists of a monomolecular layer of $\omega$-hydroxy-ceramides. These not only serve of provide a Teflon-like coating to the cell, but also interdigitate with the intercellular lipid lamellae perhaps in a Velcro-like fashion. In fact the CE is a
\end{abstract}

common feature of all stratified squamous epithelia, although its precise composition, structure and barrier function require-ments vary widely between epithelia. Recent work has shown that a number of diseases which display defective epidermal barrier function, generically known as ichthyoses, are the result of genetic defects of the synthesis of either CE proteins, the transglutaminase 1 cross-linking enzyme, or defective metabolism of skin lipids.

\section{Introduction}

Protection of the body from dehydration and noxious physical, mechanical and chemical insults from the environment is essential for terrestrial life. All beings from bacteria to plants and humans protect themselves by some form of barrier. For mammals the outermost bulwark of this defense-line are layers of terminally differentiated dead cornified cells on the surface of the epidermis of the skin.

Akin to a wall built from bricks and mortar, the cornified layer also consists of hard building blocks (the individual corneocytes) stuck together with space-filling mortar (intercorneocyte lipids). Barrier function of normal epidermis depends on the quality of its bricks and mortar. The building blocks of the epidermal barrier are formed during the complex terminal differentiation program from inner living dividing basal keratinocytes, culminating in the formation flattened cornified cells (corneocytes) which, as they are moved toward the surface, are eventually sloughed by abrasion. Each individual corneocyte consists largely of tightly bundled keratin filaments aligned roughly parallel to the skin surface ( $80-90 \%$ of total mass) encased in a sturdy bag termed the cornified cell envelope (CE) (about $10 \%$ of total mass). The CE is extremely insoluble, $\sim 15 \mathrm{~nm}$ thick, and is composed of two major parts. The protein envelope $(\sim 10 \mathrm{~nm}$ thick) is formed by covalent cross-linking of specific structural proteins by sulfhydryl oxidases and transglutaminases (TGases) (Hohl, 1990; Polakowska and Goldsmith, 1991; Reichert et al., 1993; Simon, 1994; Eckert et al., 1997). This is coated by the lipid envelope which is a $\sim 5 \mathrm{~nm}$ thick layer of lipids that are covalently attached to exterior of the protein envelope (Wertz and Downing, 1991). The lipid envelope creates cohesion between the cornified cells and the surrounding intercellular lipids, and may be essential for alignment of these lipids into lamellae (Swartzendruber et al., 1989; Wertz et al., 1989a).

This review describes our current knowledge and models of the composition and formation of the stratum corneum barrier. We also report current information on 
the molecular bases of certain inherited diseases affecting the barrier function.

\section{The cornified cell envelope}

For morphologists, the $\mathrm{CE}$ is an electron dense band located just beneath the keratinocyte plasma membrane that first appears in the most superficial granular or transitional cells of terminally differentiating stratified squamous epithelia (Brody, 1969; Hashimoto, 1969; Ishida-Yamamoto and lizuka, 1995) and gradually increases in thickness and density. Mature CEs cover and incorporate desmosomal attachment plaques and utilize proteins of those for CE assembly (Steinert and Marekov, 1995; Robinson et al., 1997; Steinert and Marekov, 1997) forming a morphologically uniform layer about $15 \mathrm{~nm}$ thick in the terminally differentiated dead cells (Jarnik et al., 1998).

The biochemist uses the term CE for the most insoluble fraction from stratified squamous epithelia, referring to the mass remaining after exhaustive removal of keratins, lipids and other solubilizable components by detergents, reducing agents (e.g. 2-mercaptoethanol), and concentrated chaotropic agents (urea, guanindine-HCl) (Steinert and Marekov, 1995). The extreme insolubility of CE in vivo is a result of macromolecular polymerization of various keratinocyte proteins by both disulfide and isopeptide bond formation. However, the disulfide bonds created by sulfhydryl oxidase (Yamada et al., 1987) are lost during $C E$ isolation procedures in order to remove the quantita-tively overwhelming keratin mass (Hohl et al., 1991a). Therefore, the in vitro analyzed CE means in practice a highly insoluble macromolecular protein polymer held together by isopeptide bonds (Hohl, 1990; Polakowska and Goldsmith, 1991; Reichert et al., 1993; Simon, 1994; Eckert et al., 1997), and may thus differ somewhat in structure and composition from the in vivo structure. Nevertheless isolated CE fragments from many types of epithelia appear as sheets uniformly 15 $\mathrm{nm}$ thick (Jarnik et al., 1998). The isopeptide bonds are formed by TGases which release ammonia from glutamine residues of substrate proteins to create a thioester acyl-enzyme intermediate, and consecutively transfer the acyl residue to primary amines (Folk and Finlayson, 1977). In biological systems the primary amine is either provided by the $\varepsilon$-amino group of a proteinbound lysine thereby creating an $N^{\varepsilon}$ - $(\gamma$-glutamyl)lysine isopeptide bond, or by a diamine (most commonly spermidine) thereby forming an $N^{1}, N^{8}$-bis $(\gamma$ glutamyl)spermidine bond (Lorand and Conrad., 1984). Although the abundance of spermidine cross-linking is minuscule in CE formation, and has been poorly investigated, this pathway might be more significant in certain pathological conditions such as psoriasis (Martinet et al., 1990).

\section{The TGases}

Human TGases constitute an evolutionarily related family of $\mathrm{Ca}^{2+}$ dependent enzymes. Seven members of the TGase family have been identified in the human genome so far, which are listed in Table 1. Four of these,

Table 1. Human transglutaminases.

\begin{tabular}{|c|c|c|c|c|c|}
\hline Enzyme & Gene locus & $\begin{array}{r}\text { Size } \\
(\mathrm{kDa})\end{array}$ & Expression & Functions & $\begin{array}{l}\text { Proteolytic } \\
\text { processing? }\end{array}$ \\
\hline $\begin{array}{l}\text { TGase } 1 \\
\text { (keratinocyte TGase) }\end{array}$ & $14 q 11.2$ & 92 & epidermis & CE formation & Yes \\
\hline $\begin{array}{l}\text { TGase } 2 \\
\text { (tissue TGase) }\end{array}$ & $20 q 11.2$ & 77 & ubiquitous & Apoptosis? & No \\
\hline $\begin{array}{l}\text { TGase } 3 \\
\text { (epidermal TGase) }\end{array}$ & $20 q 11.2$ & 77 & epidermis & CE formation & Yes \\
\hline $\begin{array}{l}\text { TGase } 4 \\
\text { (prostate TGase) }\end{array}$ & $3 p 21-22$ & 75 & prostate & $\begin{array}{l}\text { clotting of the } \\
\text { seminal plasma }\end{array}$ & Yes \\
\hline Factor XIII & $6 p 24-25$ & 80 & $\begin{array}{c}\text { platelets, } \\
\text { histiocytes, } \\
\text { megakaryocyts }\end{array}$ & blood clotting & Yes \\
\hline Band 4.2 & $15 q 15$ & 72 & $\begin{array}{l}\text { erythroblasts } \\
\text { erythrocytes }\end{array}$ & $\begin{array}{l}\text { structural } \\
\text { protein }\end{array}$ & Inactive \\
\hline TGase X & $?$ & $81 ?$ & keratinocytes? & $?$ & $?$ \\
\hline
\end{tabular}


TGases 1, 2, 3 and $\times$ are commonly expressed in epithelia such as the epidermis (Kim et al., 1991; Aeschlimann et al., 1998), although to date only TGases 1 and 3 have proven importance in CE assembly (Candi et al., 1995; Tarcsa et al., 1997; Tarcsa et al., 1998 Candi et al., 1999). It has also been proposed that the cross-linking by these enzymes coordinates mechanically the association between the CE and the underlying intracellular keratin intermediate filaments (Candi et al., 1998a), and perhaps also in the bundling of keratin filaments (Clement et al., 1998).

The TGM1 gene encoding the TGase 1 enzyme is located on chromosome 14q11.2 (Yaminishi et al., 1990; $\mathrm{Kim}$ et al., 1992). The synthesis of TGase 1 is regulated in cultured keratinocytes by various stimuli, including phorbol esters, retinoids and corticosteroids (Floyd and Jetten, 1989; Liew and Yamanishi, 1992; Yamada et al., 1994) and by intercellular $\mathrm{Ca}^{2+}$ concentrations, presumably by AP-1 mediated gene regulatory signals (Dlugosz and Yuspa, 1994; Mariniello et al., 1995). In epithelia such as the epidermis, TGase 1 expression is induced shortly after commitment to terminal differentiation (Michel et al., 1992), although a minor degree of TGase 1 expression is detectable in undifferentiated basal keratinocytes (Schroeder et al., 1992; Kim et al., 1995a). The bulk of the TGase 1 enzyme is bound to the plasma membranes by its constitutively $\mathrm{N}$ - and $\mathrm{S}$-fatty acylated $10 \mathrm{kDa}$ amino terminal part (Rice et al., 1990; Phillips et al., 1993; Steinert et al., 1996a). During terminal differentiation, some of the full-length TGase 1 enzyme undergoes proteolytic cleavage into fragments of apparent electrophoretic mobility of $10 / 67 / 33 \mathrm{kDa}$ which are held together by secondary forces and thus remain membrane-bound (Steinert et al., 1996b). This 10/67/33 kDa complex shows a 200 -fold higher specific activity in standard in vitro
TGase assays (Kim et al., 1994; Kim et al., 1995b). Also, some of the $67 \mathrm{kDa}$ fragment harboring the catalytic activity may cycle off the membranes and thus might contribute to cross-linking at sites remote from the plasma membrane. However, the mechanisms by which the TGase 1 enzyme is proteolytically activated remain unexplored.

The TGM2 and TGM3 genes encoding the TGase 2 and 3 enzymes are located close to each other on chromosome 20q11.2 (Wang et al., 1994). Expression of TGase 3 in cultured keratinocytes is triggered by elevated extracellular $\mathrm{Ca}++$ presumably through adjacent cooper-ating Ets and Sp1 transcription factors (Lee et al., 1996). TGase 3 is translated as a soluble inactive proenzyme of $77 \mathrm{kDa}$, and is subsequently activated by proteolysis at a flexible loop sequence into an amino-terminal $50 \mathrm{kDa}$ domain harboring the active site and the carboxy-terminal $27 \mathrm{kDa}$ portion (Negi et al., 1985; Kim et al., 1990; Kim et al., 1993). No diseases have yet been linked to muta-tions in the TGM3 gene.

\section{Structural protein components of CEs}

Table 2 lists proven CE protein constituents.

Involucrin is ubiquitously expressed in stratified squa-mous epithelia, thus suggesting it is commonly involved in CE formation. The involucrin gene is located in a cluster with the genes for numerous other CE proteins in the so-called epidermal differentiation complex (EDC) region on chromosome 1q21 (Volz et al., 1993; Mischke et al., 1996). The involucrin gene has a single exon encoding the entire protein (Eckert and Green, 1986) and shows astonishing polymorphism in humans (Simon et al., 1991; Djian et al., 1995). Mammalian involucrins evolved from a common ancestor gene by tandem duplications of a $45-60$ base pair sequence in prosimians

Table 2. CE precursor proteins

\begin{tabular}{|c|c|c|c|c|}
\hline Name & Gene locus & Size (kDa) & $\begin{array}{l}\text { Relative abundance } \\
\text { in human foreskin } \\
\text { CE }\end{array}$ & $\begin{array}{l}\text { Cross-linking } \\
\text { sites identified } \\
\text { in vivo? }\end{array}$ \\
\hline Involucrin & 1q21 (EDC) & 65 & $2-5 \%$ & Yes \\
\hline Loricrin & 1q21 (EDC) & 26 & $80 \%$ & Yes \\
\hline SPRs & $1 q 21$ (EDC) & $6-26$ & $3-5 \%$ & Yes \\
\hline Cystatin A & 3cen-q21 & 12 & $2-5 \%$ & Yes \\
\hline Proelafin & $20 q 12-q 13$ & 10 & $<1 \%$ & Yes \\
\hline (Pro)filaggrin & 1q21 (EDC) & $>400$ & $<1 \%$ & Yes \\
\hline Type II keratins & $12 q 13$ & $56-60$ & $<1 \%$ & Yes \\
\hline Desmoplakin & 6p21-ter & $330 / 250$ & $<1 \%$ & Yes \\
\hline Envoplakin & $17 q 25$ & 210 & $<1 \%$ & Yes \\
\hline Periplakin & $16 p 13.3$ & 195 & $<1 \%$ & Yes \\
\hline S100 proteins & 1q21 (EDC) & 12 & $<1 \%$ & No \\
\hline Annexin I & $9 q 12-q 21.2$ & 36 & $<1 \%$ & No \\
\hline
\end{tabular}


and which changed to a 30 base pair sequence in higher monkeys (Tseng and Green, 1988; Green and Djian, 1992). For example, pig involucrin has 13 repeats of 16 amino acids, of which seven are glutamine and three are glutamic acid residues. Human involucrin has 37 repeats of 10 residues of which three are glutamines and two are glutamates. Thus the whole human involucrin protein contains $\sim 25 \%$ glutamine and $\sim 20 \%$ glutamate residues (Eckert and Green, 1986). Presumably, the expansion of these repeat sequences was driven by the evolutionary benefit of increasing the number of potential TGase substrate glutamine residues for cross-linking, and perhaps of lengthening the molecule. This repeat region is flanked on both the amino and carboxy termini by domains which have been remarkably conserved throughout mammalian evolution and indeed show significant sequence homology to similar regions on other EDC-encoded CE structural proteins such as loricrin and the small proline rich proteins (Gibbs et al., 1993). Involucrin is a rod-like, elongated protein of $\sim 45 \mathrm{~nm}$ long and $1.5 \mathrm{~nm}$ in diameter. Thus involucrin is ideally suited for crossbridging widely separated CE components (Yaffe et al., 1992), although only a small fraction of its 150 glutamines appear to be utilized in vivo (Steinert and
Marekov, 1997). The repeat region is mostly $\alpha$-helical in humans but other secondary structures have also been proposed for the prosimian repeats (Downing, 1992). Expression of involucrin appears at the onset of terminal differentiation in epithelia (Eckert et al., 1993). In cultured keratinocytes in vitro, involucrin expression is induced

Figure 1. Schematic model of the structure of the $\mathrm{CE}$ and the lipid barrier. Modified from ref. 27 . An initial scaffold 2-3 $\mathrm{nm}$ thick is built at the cell periphery by deposition of involucrin (long green rods) onto periplakin, envoplakin and perhaps desmosomal components such as desmoplakin. In the $\mathrm{CE}$ of the epidermis as shown, the subsequent reinforcement proteins are composed mostly of loricrin and interconnecting SPRs. In the CEs of the forestomach, trichohyalin is also used (Steinert et al., 1998b). In the CEs of other internal stratified squamous epithelia, the reinforcement proteins are mostly SPRs. In the hair fiber cuticle, other so far uncharacterized cysteine-rich proteins are used (Zahn et al., 1997). The KIF cytoskeleton is thought to be directly crosslinked to the cytoplasmic surface of the $\mathrm{CE}$ in order to mechanically integrate cornified cell structure (Candi et al., 1998a). In all cases examined so far, the protein envelope of the CE is uniformly $10 \mathrm{~nm}$ thick (Jarnik et al., 1998). In the epidermal CE, a lipid envelope of about $5 \mathrm{~nm}$ thick is also present, which is formed from a monomolecular layer of unusually large ceramides (vertical yellow rods). These may serve to interdigitate with other intercellular corneocyte lipids to complete the skin barrier.

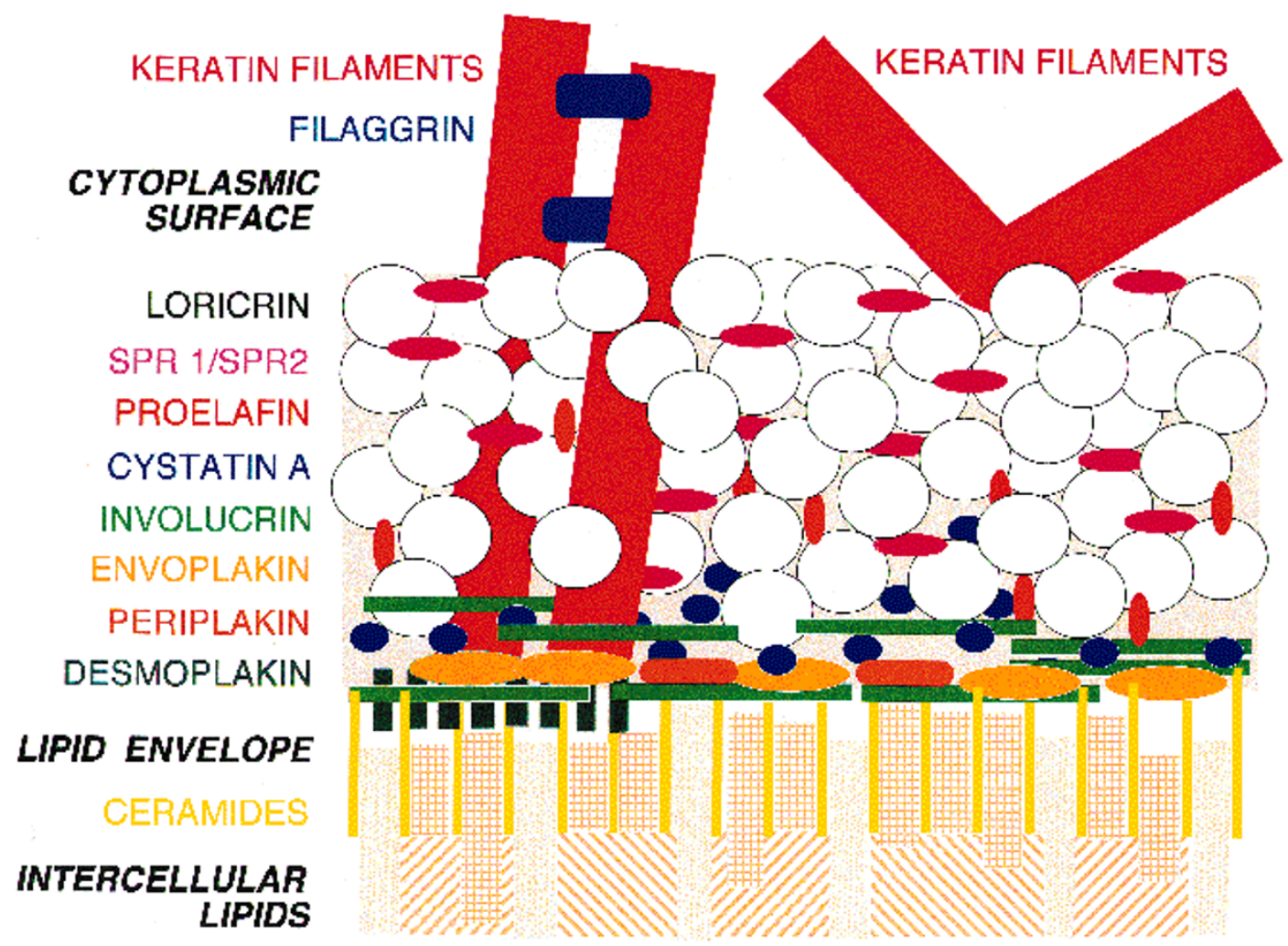


by calcitriol (Su et al., 1994), corticosteroids (Cline and Rice, 1983), phorbol esters (Takahashi and lizuka, 1993), and $\mathrm{Ca}^{2+}$ (Younus and Gilchrest, 1992), by regulatory elements located within about the first $2.5 \mathrm{~kb}$ upstream of the cap site (Welter et al., 1995; Lopez-Bayghen et al., 1996; Welter et al., 1996; Crish et al., 1998). CEs from 'dry' epithelia such as human foreskin epidermis contain about 5\% involucrin (Steinert and Marekov, 1997). However, it is much more abundant in the CEs recovered from cultured keratinocytes (Rice et al., 1979; Yaffe et al., 1993; Steven and Steinert, 1994; Robinson et al., 1996) or internal 'wet' epithelia [P.M.S., unpublished].

Loricrin accounts for $>70 \%$ of the protein mass of epidermal CEs, but rather less (30-50\%) in the CEs of certain internal epithelia such as the esophagus, palate, buccal mucosa (Hohl et al., 1991a; Yoneda and Steinert, 1993), and is not expressed in many other internal epithelia. Expression of loricrin is induced by phorbol esters, cell confluence, and $\mathrm{Ca}^{2+}$ (Hohl et al., 1991b; Dlugosz and Yuspa, 1993), presumably through signals acting through an AP1 site (DiSepio et al., 1995; Rossi et al., 1998), and occurs very late during the terminal differentiation program of these tissues. Loricrin is an insoluble protein under physiological conditions, apparently due to its high content of glycine, serine and cysteine: indeed it has the highest glycine content of any protein known in biology (Mehrel et al., 1990; Hohl et al., 1991a; Yoneda et al., 1992). Owing to its high rate of expression and low solubility, loricrin forms spherical inclusions, called L-bodies in newborn mouse skin, human foreskin and acrosyringium, but it is diffusely distributed in the cytoplasm of adult epithelia (Steven et al., 1990; Ishida-Yamamoto et al., 1993; Ishida-Yamamoto et al., 1996). Loricrin contains three glycine rich domains which are thought to form uniquely flexible glycine loops (Steinert et al., 1991), interspersed by glutamine-rich motifs and flanked by lysine- and glutamine-rich amino and carboxy terminal domains (Mehrel et al., 1990; Hohl et al., 1991a). In vitro cross-linking experiments using recombinant human loricrin have demonstrated that the TGase 1 and 3 enzymes utilize different glutamine and lysine residues, implying that both enzymes have distinctly complementary and essential functions in the utilization of loricrin for CE assembly in vivo (Candi et al., 1995).

Small proline rich proteins (SPRs, cornifins, pancornulins) are a family of 11-14 closely related proteins. Three classes of SPRs have been identified: SPR1 (two members), SPR2 (8-11 members) and SPR3 (1 member) (Kartasova and van de Putte, 1988; Kartasova et al., 1988a; Marvin et al., 1992; An et al., 1993; Gibbs et al., 1993; Greco et al., 1995; Hohl et al., 1995; Austin et al., 1996; Kartasova et al., 1996; Steinert et al., 1998a; Song et al., 1999). The various members of the SPR classes display wide variations of expression in different epithelia. For example, SPR1a (cornifin $\alpha$ ) and certain SPR2 proteins are expressed in dry epithelia such as the epidermis; distinctly different members of the SPR2 class are expressed in internal epithelia; and SPR3 is abundantly expressed in mucosal epithelia exposed to mechanical stress, such as the esophagus and rodent forestomach, while it is absent in the epidermis (Fujimoto et al., 1993; Hohl et al., 1995; Steinert et al., 1998b; Song et al., 1999). However, most members are induced in response to UV damage and phorbol esters (Kartasova and van de Putte, 1988; Kartasova et al., 1988b; Gibbs et al., 1990) or malignancy (Yaar et al., 1995). SPR1 and 2 transcription is induced by $\mathrm{Ca}^{2+}$ through a complex array of interacting AP1, Sp1, ets and other transcription factors (Fischer et al., 1996; Sak et al., 1998). All SPRs are built from a variable number of eight (in SPR1 and SPR3) or nine (in SPR2) amino acid residue proline-rich repeats. The number of repeats ranges from three in human SPR2 to 23 in human SPR3, so that the mass of SPRs varies between $6 \mathrm{kDa}$ to $25 \mathrm{kDa}$ (Fujimoto et al., 1993; Gibbs et al., 1993; Austin et al., 1996; Kartasova et al., 1996; Steinert et al., 1998b; Song et al., 1999). The repeats are flanked by short glutamine-, lysine- and proline-rich amino and carboxy terminal domains showing distant homology to the head and tail regions in involucrin and loricrin (Gibbs et al., 1993). Recombinant human SPR2 (Candi et al., 1999) and SPR1 (Tarcsa et al., 1998) proteins have been studied in vitro. Circular dichroism measurements indicate a random coil secondary structure for the termini, but a limited protein turn conformation for the repeat motifs. Both are powerful TGase substrates, and many adjacent glutamine and lysine residues become cross-linked in vitro and in vivo (Steinert et al., 1998a). Interestingly different residues on the amino termini are used by the two enzymes, indicating that both enzymes are also required for the appropriate assimilation of SPRs into the CE in vivo. In addition, double cross-linking experiments have shown that the TGase 3 enzyme first cross-links the SPRs into short oligomers, which are later affixed to the CE by the TGase 1 enzyme (Candi et al., 1999). We have noted a correlation between the amount of SPRs present in CEs and the presumed requirements of epithelia for resistance to physical trauma. For example, trunk epidermis contains only traces of SPRs; foreskin epidermis contains about 5\% SPRs; human palm/sole or rodent footpad and lip epidermis contain $10-15 \%$ SPRs; rodent esophagus and forestomach epithelia contain $>20 \%$ SPRs; and human buccal and gingiva epithelia contain near 50\% SPRs. We have proposed the SPRs serve as cross-bridging proteins and in this way directly modulate the biomechanical properties of the CE and the entire epithelium in which they are expressed (Steinert et al., 1998a; Steinert et al., 1998b).

Cystatin A (keratolinin) expression is inducible in cultured keratinocytes by $\mathrm{Ca}^{2+}$, phorbol esters and forskolin (Takahashi et al., 1997). In epidermis it is 
expressed in the spinous layer (Jarvinen et al., 1987). Cystatin A is a substrate for epidermal TGases and has been identified as a minor cross-linked component of CEs (Zettergren et al., 1984; Takahashi et al., 1992; Steinert and Marekov, 1997). The protein is a known cysteine protease inhibitor (Jarvinen et al., 1987; Takahashi et al., 1994; Shibuya et al., 1995) and it has been suggested that this feature might be relevant for the bacteriostatic properties of the skin (Takahashi et al., 1994).

Elafin (elastase specific inhibitor, SKALP; skin derived anti-leukopeptidase) is a minor component of CEs from normal adult epidermis, is transiently expressed in fetal and neonatal epidermis, but is highly expressed in wounded or psoriatic skin and in cultured keratinocytes (Molhuizen et al., 1993; Schalkwijk et al., 1993; Alkemade et al., 1994; Nonomura et al., 1994; Pfundt et al., 1996). The protein is translated as preproelafin, which is curtailed to proelafin after the removal of the 25 amino acid signal peptide. Proelafin is composed of an amino terminal 34 amino acid proline-rich sequence ("cementoin") and the 57 amino acid long elafin (Wiedow et al., 1990; Schalkwijk et al., 1991; Saheki et al., 1992; Sallenave et al., 1993; Wiedow et al., 1993). Though elafin has potent elastase and proteinase- 3 inhibitory properties (Wiedow et al., 1990; Wiedow et al., 1993), the biological relevance of this is unknown in keratinocytes. The fate of proelafin after synthesis is somewhat obscure, as the protein is stored in secretory granules and is later extruded from the cells (Pfundt et al., 1996). However, TGases utilize glutamine residues in the cementoin sequence as sub-strates (Molhuizen et al., 1993), and proelafin has been identified as a crosslinked component of epidermal CEs (Steinert and Marekov, 1995; Steinert and Marekov, 1997).

Profilaggrin is a major differentiation product of orthokeratinizing epithelia such as the epidermis (Gan et al., 1990 ), and its gene is encoded in the EDC (McKinleyGrant et al., 1989). Profilaggrin is a polyprotein consisting of numerous filaggrin units flanked by distinctive amino and carboxy terminal domains (Presland et al., 1992; Markova et al., 1993). Interestingly, the amino terminus of profilaggrin contains two functional calcium binding EF hand motifs (Presland et al., 1992; Markova et al., 1993). Filaggrin is released by proteolysis from profilaggrin (Presland et al., 1997), and functions to bind keratin intermediate filaments into tight arrays typically seen in corneocytes (Dale et al., 1978; Mack et al., 1993). Some filaggrin becomes cross-linked to CE proteins (Richards et al., 1988; Steinert and Marekov, 1995; Simon et al., 1996), presumably together with and at the same time as the keratins. It has also been proposed that the amino terminal parts of profilaggrin are also incorporated into CEs after proteolytic cleavage from the filaggrin units (Presland et al., 1997).

Keratin intermediate filaments (KIF) are of course the major protein of the corneocyte, and some keratin proteins become cross-linked to the peripheral CE during terminal differentiation (Steinert and Marekov, 1995; Steinert and Marekov, 1997; Candi et al., 1998a). KIF and their roles in health and disease have been reviewed in detail elsewhere (Parry and Steinert, 1995; Steinert, 1996). In living nucleated epithelial cells the KIF cytoskeleton is attached to the cell periphery at desmosomal junctions, which provides mechanical stability throughout the epithelium (Holbrook and Wolff, 1993; Garrod et al., 1996). Although the exact details are unknown, the connection of the KIF to desmosomes occurs through several desmosomal proteins, including desmoplakin and envoplakin (Garrod et al., 1996; Green and Jones, 1996; Fuchs et al., 1997). In the course of terminal differentiation and CE formation, the structural integrity of desmosomes is destroyed at the same time as many normal house keeping cellular constituents are absorbed. During this process, KIF become cross-linked to the CE primarily through a single lysine residue located in the aminoterminal head domain of the type II keratins 1, 2e, 5, 6, typically expressed in stratified squamous epithelia (Candi et al., 1998a). In this way, the KIF cytoskeleton becomes integrated mechanically with the CE to form a stable insoluble structure for the corneocyte.

Desmoplakin is a major intracellular desmosomal plaque protein. Two isoforms, DPI and DPII, result from alternative splicing. In stratified squamous epithelia both isoforms are expressed (Virata et al., 1992). A large body of evidence indicates that the KIF meet at the site of the desmosome where they may interact directly or indirectly through various other intermediary proteins, with the terminal domains of desmoplakin (Green et al., 1990; Virata et al., 1992; Kouklis et al., 1994; Garrod et al., 1996; Green and Jones, 1996; Fuchs et al., 1997). There is direct evidence from protein sequencing that desmo-plakin becomes crosslinked to a variety of other CE proteins, although interestingly, the crosslink connection with the type II keratins seems to be indirectly through other proteins (Steinert and Marekov, 1995; Steinert and Marekov, 1997; Candi et al., 1998a). Several other desmosomal proteins including desmoglein 3, desmo-collins 3A/3B, plakoglobin, and plakophilin were found among proteolyzed $C E$ fragments (Robinson et al., 1997). However, the sites of isopeptide bond formation were not identified in them, and the conclusion that they are in fact integral CE components awaits verification. Two other proteins, envoplakin and periplakin, which are structural homologues of desmoplakin, are located at or between the desmosome junctions of stratified squamous epithelia (Ruhrberg et al., 1996; Ruhrberg et al., 1997). These become crosslinked components of mature CEs, and indeed, envoplakin seems to mediate linkages between desmoplakin and KIF (Steinert and Marekov, 1997; Candi et al., 1998a). 
The $\mathrm{S} 100$ proteins are akin to the amino-terminal domain of profilaggrin in that they contain two calcium binding EF hand motifs (Engelkamp et al., 1993; Volz et al., 1993; Moog-Lutz et al., 1995; Mischke et al., 1996). Many of their genes are located in the EDC region of chromosome 1q21. Among these, S100A10 (calpactin, light chain) and S100A11 (S100C, calgizzardin) are expressed and incorporated into CE in cultured keratinocytes (Robinson et al., 1997). On binding calcium, these proteins expose hydrophobic domains on their surface and bind to several proteins, including annexin I (Seemann et al., 1996).

Annexin I (lipocortin 1) is a member of the multigene family of annexins expressed in all eukaryotic kingdoms except fungi (Morgan and Fernandez, 1997). Annexins are structurally defined by an ancient conserved domain of four homologous repeats responsible for ion channel activity and calcium dependent binding to anionic phospholipids, the cytoskeleton and extracellular matrix proteins (Liemann and Lewit-Bentley, 1995). Annexin I is abundantly expressed in most tissues, although its precise role remains to be elucidated. Annexin I was found to be a component of CEs from cultured keratinocytes (Moore and Sartorelli, 1992; Robinson et al., 1997), a finding not yet corroborated by in vivo data. As annexins I and II were shown to associate with $\mathrm{S} 100$ proteins on calcium binding (Mailliard et al., 1996; Seemann et al., 1996), this mechanism may play a role in docking certain early CE protein components to the plasma membrane (Robinson and Eckert, 1998).

\section{The order of CE assembly}

As CEs consist of many different proteins, the relative ratios of which vary widely between different epithelia, it would be parsimonious to assume that these proteins are cross-linked to one another in a random fashion, when keratinocyte $\mathrm{Ca}^{2+}$ concentrations reach sufficiently high levels to activate TGases (Michel et al., 1987; Reichert et al., 1993). This random copolymerization, or so-called 'dustbin' hypothesis, does not explain the structure of $\mathrm{CE}$, and moreover, seems inconsistent with the known orderly expression of the various protein components. Several studies indicate that the CE is formed by sequential deposition of consecutively-expressed proteins, apparently starting with the fixation of involucrin on the intracellular surface of the plasma membrane (Eckert et al., 1993; Steinert, 1995; Steinert and Marekov, 1997). Initially the CE appears as a thickened electron dense band between the desmosomes, which later overlayers the desmosomal attachment plaques, which presumably are not only masked but also degraded during the terminal differentiation process (Green and Jones, 1996). Expres-sion studies have shown that involucrin deposition at the cell periphery precedes that of most other CE proteins (Rice et al., 1979; Watt and Green, 1981; Simon and Green, 1984; Crish et al., 1993; Murthy et al., 1993; Yaffe et al., 1993; de Viragh et al., 1994; Jarnik et al., 1998; Song et al., 1999). Further, immunogold labeling and ultrastructural data have suggested that a monomolecular layer of involucrin is first deposited as a scaffold (Steinert and Marekov, 1997; Jarnik et al., 1998). In addition, sequential digestion and protein sequencing of foreskin CEs has revealed that involucrin is cross-linked to other peripheral CE proteins including desmoplakin, envoplakin, and perhaps periplakin. Finally, we have shown that involucrin is covalently bound to $\omega$-hydroxyceramides from the exterior surface of the CE, indicating that involucrin must have been deposited in the intimate vicinity of the cell membrane at an early time (Marekov and Steinert, 1998). A transporting system has been proposed for positioning involucrin to the cell membrane (Robinson and Eckert, 1998). This model hypothesizes cross-linking of CE building blocks first to $\mathrm{S} 100$ proteins, which then dock to annexins to attach to the inner memb-rane surface in a calcium and phospholipid dependent manner. An alternative model has been proposed. We (Nemes et al., 1999) have shown that involucrin can bind to the plasma membrane in a calcium and phosphatidyl-serine dependent manner and serve as substrate for membrane-bound TGase 1 . Thus involucrin and TGase 1 might form the initial scaffold of the CE without the need for any other transporter or organizer proteins.

Current models suggest that a monomolecular layer of involucrin is then used as a scaffold for the subsequent attachment of other 'reinforcement' proteins (Hohl, 1990; Reichert et al., 1993; Eckert et al., 1997; Steinert and Marekov, 1997; Jarnik et al., 1998). In the case of the epidermis, these reinforcement proteins include loricrin and SPRs, which together comprise about $85 \%$ of the total mass of the CE (Steinert and Marekov, 1997; Steinert et al., 1998b). The forestomach also includes significant amount of trichohyalin (Steinert et al., 1998b). The CEs from other internal epithelia which do not express loricrin have much higher contents of SPRs instead [P.M.S., un-published]. The CEs of the hair cuticle use as yet unknown cysteine-rich proteins (Zahn et al., 1997). These differ-ences presumably reflect the different barrier function requirements of different epithelia (Steinert et al., 1998b). In addition, there is considerable functional redundancy in CE proteins and their subsequent cross-linking. For example, the complete lack of loricrin in the knock out mouse model resulted in a surprisingly mild phenotype: newborns had an abnormal epidermis with diminished barrier function, but this improved by five days after birth. This improvement was concurrent with increased expression of SPRs (de Viragh et al., 1997). 


\section{The mortar}

Terminal differentiation of keratinocytes is accompanied by vigorous lipid metabolism and synthesis of keratinization-specific lipids in the granular layer (Swartzendruber et al., 1989; Wertz et al., 1989a; Schurer et al., 1991; Wertz and Downing, 1991; Downing et al., 1993; Elias, 1996). Newly synthesized lipids are accumulated and temporarily stored in small cytoplasmic inclusions known as lamellar bodies, in which the lipids are arranged as multilayered stacks (Landmann, 1980). These layers are held together by extremely long $\omega$-acylceramides spanning over several lipid layers (Abraham et al., 1988). The lamellar body lipids consist predominantly of acylated/glucosylated/hydroxylated ceramides, cholesterol and its acyl and sulfate esters, and free fatty acids (Schurer et al., 1991; Downing et al., 1993; Elias, 1996). In the upper granular layer the lamellar bodies are extruded into the intercellular space, forming broad multilamellar lipid sheets (Landmann, 1986). Ultrastructural examination of lamellar bodies as well as intercorneocyte lipids display a parallel pattern of electron dense and lucent bands (Madison et al., 1988; Swartzendruber et al., 1995). The dense bands correspond to the polar head groups of the lipid layers, while lucent bands are occupied by the apolar hydrocarbon chains (Swartzendruber et al., 1989). On extrusion, the bounding membrane of the lamellar bodies is fused with the plasma membrane of the keratinocytes (Ricardo Martinez and Peters, 1971). This process apparently coincides with the initiation of $C E$ assembly inside the cells. One minor but important component of the extruded lipids are the $\omega$-hydroxyceramides, which become covalently attached to the outer surface of the protein envelope of the CE forming an $\sim 5 \mathrm{~nm}$ thick lipid envelope coat surrounding each corneocyte (Swartzendruber et al., 1987; Wertz and Downing, 1987a; Wertz et al., 1989b). The ceramides are attached by way of ester bonds to glutamic acid and glutamine residues of several CE proteins, including involucrin, envoplakin and periplakin (Wertz et al., 1989b; Marekov and Steinert, 1998). The protein-bound $\omega$-hydroxyceramides are built from sphingosine coupled to highly saturated, uniquely long $\left(\mathrm{C}_{30-36}\right)$ chain fatty acids having a chain terminal (" $\omega$ ") hydroxyl group (Wertz and Downing, 1991). This functional group is presumably involved in the ester bond formation, although incomplete conversion of protein-bound ceramides to their acetonides by acidic acetone indicated that sphingosine hydroxyls may also be used (Wertz and Downing, 1987a).

Isolation and sequencing of ceramide-peptide ester adducts from proteolyzed foreskin epidermal CEs located possible lipid attachment sites in involucrin and desmosomal proteins. These included both glutamate and glutamine residues (Marekov and Steinert, 1998). Thermodynamic considerations necessitate high-energy intermediate formation to drive formation of ester bonds in biology. Ester formation on glutamate residues presumably involves transferases using nucleotide triphosphate as the energy source, and indeed many transferases are present in lamellar body exudate (Downing et al., 1993; Elias, 1996). However, glutamines are an intrinsically activated derivative of glutamic acid and the release of ammonia from its carboxamido groups provides sufficient entropy increase to drive ester formation. TGases (precisely: glutamine-amine aminotransferases) are known to utilize the lysis of glutamine carboxamido moieties to drive thermodynamically difficult reactions, including activation of alcohol moieties to form esters (Gross and Folk, 1974; Folk and Finlayson, 1977; Lorand and Conrad., 1984). Thus we propose that TGases may also participate in lipid envelope formation by covalent attachment by esterification of $\omega$-hydroxyceramides to glutamines of the protein envelope.

The long chain ceramides comprising the lipid envelope attached covalently to the surface of the CE function in large part by interdigitation with the intercorneocyte lipids in a Velcro-like fashion. As part of its obviously important water barrier function, this attachment presumably permits 'fixation' of the cornified cells after disappearance of desmosomal linkages, and may have a role in inhibiting the clumping, vacuolization or other derangement of the lipid lamellae (Wertz et al., 1989a; Wertz, 1997), especially in hair cuticle cells (Zahn et al., 1997).

\section{Defects of the skin barrier}

\section{Broken bricks}

More than 10 different diseases involving the genes encoding KIF (which comprise the bulk of epithelial cells) are now known and have been described in detail elsewhere (Parry and Steinert, 1995; Steinert, 1996). Included in these is a novel mutation involving the loss by mutation of a single lysine residue in the head domain of the keratin 1 gene, resulting in nonepidermolytic palmar-plantar keratoderma (Unna-Thost disease). This disease is characterized by pathological thickening of the stratum corneum of the palms and soles (tylosis) (Kimonis et al., 1994). The lysine residue has been shown to be essential for the crosslinking of KIF to CE structural pro-teins, and its loss appears to interfere with the orderly structure of the corneocyte (Candi et al., 1998a).

In addition, a few genetic diseases caused by defects in the genes encoding either CE structural proteins or TGase 1 are now known. Defective forms of loricrin dis-rupt the terminal differentiation program of keratinocytes and cause skin diseases. Frameshift mutations, resulting in loss of key glutamine and lysine 
residues for cross-linking, and expression of an aberrantly highly positively charged protein which accumulates in the nucleus instead, cause the autosomal dominant diseases Vohwinkel's keratoderma (keratoderma hereditaria mutilans (Vohwinkel, 1929; Gibbs and Frank, 1966; Korge et al., 1997; Lam et al., 1997) or progressive symmetric erythrokeratoderma (IshidaYamamoto et al., 1997). In these diseases the CE is thinner than normal and contains less loricrin (IshidaYamamoto et al., 1997; Korge et al., 1997; Lam et al., 1997). Patients with Vohwinkel's keratoderma have diffuse palmoplantar hyperkeratosis with small "honeycomb" depressions and progressively develop constricting bands on their fingers. Irregularly shaped keratoses on the backs of feet and hands, elbows and knees and variable deafness are also part of the syndrome. Progressive symmetric erythrokeratoderma is characterized by wide-spread erythematous keratotic plaques (Ishida-Yamamoto et al., 1998).

Genetic defects of the TGM1 gene encoding TGase 1 cause the devastating life threatening disease lamellar ichthyosis, which manifests as large brown plate-like scaling throughout the body, accompanied by ectropion and/or eclabium, scarring alopecia and diminished skin barrier function (Huber et al., 1995a; Russell et al., 1995). Several mutations have been identified which cause non-sense, frameshift or splice site changes affecting either the active site of the enzyme (Parmentier et al., 1995; Huber et al., 1997; Petit et al., 1997; Candi et al., 1998b) or its posttranslational proteolytic processing (Candi et al., 1998b). In all of these cases, the amount of TGase 1 activity is greatly diminished or lost (Hohl et al., 1998; Raghunath et al., 1998). Several of these phenotypic changes are also apparent in the mouse TGM1 gene knock-out model (Matsuki et al., 1998). Thus the TGase 2, 3 and $X$ enzymes also co-expressed in the epidermis are unable to replace the missing TGase 1 activity. Interestingly, however, other internal epithelia which also express TGase 1 and other TGases are not affected in lamellar ichthyosis. Thus it is possible that debilitating epidermal involvement may be due to the inability of TGase 1 to attach ceramide lipids to the CE. In addition, there are a variety of other autosomal recessive ichthyoses that are unlinked to the TGM1 locus, indicating that defects in other genes cause a phenotype similar to lamellar ichthyosis (Huber et al., 1995b; Bale et al., 1996; Hennies et al., 1998). One possibility is that these genes encode proteins involved in the posttranslational proteolytic activation of the TGase 1 enzyme (Candi et al., 1998b). Finally, to date, no disease has been linked to any of the other TGase genes expressed in epithelia.

\section{Weak mortar}

Production of an effective lipid barrier in the skin (and other epithelia) involves an extraordinarily complex set of machinery and a very large (indeed, unknown) number of genes. Generally, deficiencies in barrier function result in an ichthyosiform disease. Even minor depletion of the lipid barrier causes dry skin, a common manifestation of which is the scaling caused by exaggerated application of hygienic detergents. Essential fatty acid deficiency causes excess scaling in rats (Wertz et al., 1987b) and also in humans on long-term intravenous alimentation lacking linolate (Friedman, 1986). The systemic application of HMG-CoA reductase inhibitors impedes epidermal cholesterol synthesis and might cause ichthyosiform symptoms (Williams, 1992). Excessive depletion of the cornified layer triggers hyperproliferation often leading to abnormal scaling (Fartasch, 1997).

Many subtypes of ichthyoses have been distinguished on the basis of ultrastructural (Anton-Lamprecht, 1994) or other criteria based on abnormal intercellular deposition of apolar lipids, cholesterol, polar lipids, etc (Williams and Elias, 1987; Traupe, 1989). The exact genetic defect in the vast majority of these classified diseases is not yet known, although some have been identified. As discussed above, lamellar ichthyosis is caused by mutations in the TGM1 gene encoding the TGase 1 enzyme; the disease may result from the inability to both crosslink structural proteins and attach ceramides. $\mathrm{X}$-linked ichthyosis is due to cholesterol sulfate accumulation owing to a deficiency of the arylsulfatase $\mathrm{C} /$ cholesterol sulfatase gene (Shapiro et al., 1978; Kubilus et al., 1979; Baden et al., 1980). How abnormally high levels of cholesterol sulfate cause barrier dysfunction has not yet been clearly elucidated (Zettersten et al., 1998), although the TGM1 gene may be involved (Kawabe et al., 1998). Some ichthyoses are the direct result of genetic defects of lipid metabolism, as exemplified by Refsum's disease (phytanic acid accumul-ation owing to phytanoyl-CoA hydroxylase deficiency) (Steinberg et al., 1978; Jansen et al., 1997), and Sjogren-Larsson's syndrome (pathological lipid metabolism owing to fatty aldehyde dehydrogenase deficiency (De Laurenzi et al., 1996; De Laurenzi et al., 1997). Similarly, maple syrup urine disease in cattle is caused by an inherited deficiency in the enzyme branched chain alpha-ketoacid dehydrogenase, which leads to accumulated branched chain amino acids (valine and isoleucine). A hair fiber barrier defect is also evident because of loss of a key lipid, 18-methyleicosanoic acid, which is a downstream metabolite of the enzyme (Zhang et al., 1990).

\section{Conclusion}

In recent years substantial progress has been made to identify the protein and lipid components involved in skin barrier function. Nevertheless, several major problems still await resolution in order to provide a complete understanding of the biochemical mechanisms of barrier 
formation as well as the temporal and geometric interactions of the individual components. Thus, much additional basic research is essential to understand the bases of genetic diseases barrier function before rational therapy procedures can be developed.

\section{References}

Abraham, W., Wertz, P. W. and Downing, D. T. (1988) Effect of epidermal acylglucosylceramides and acylceramides on the morphology of liposomes prepared from stratum corneum lipids. Biochim. Biophys. Acta 939: 403-408

Aeschlimann, D., Koeller, M. K., Allen-Hoffmann, B. L. and Mosher, D. F. (1998) Isolation of a cDNA encoding a novel member of the transglu-taminase gene family from human keratinocytes. Detection and identifi-cation of transglutaminase gene products based on reverse transcription-polymerase chain reaction with degenerate primers. J. Biol. Chem. 273: 3452-3460

Alkemade, J. A., Molhuizen, H. O., Ponec, M., Kempenaar, J. A., Zeeuwen, P. L. and de Jongh, G. J. (1994) SKALP/elafin is an inducible proteinase inhibitor in human epidermal keratinocytes. J. Cell Sci. 107: 2335-2342

An, G., Tesfaigzi, J., Chuu, Y. J. and Wu, R. (1993) Isolation and charac-terization of the human spr1 gene and its regulation of expression by phorbol ester and cyclic AMP. J. Biol. Chem. 268: 10977-10982

Anton-Lamprecht, I. (1994) Ultrastructural identification of basic abnor-malities as clues to genetic disorders of the epidermis. J. Invest. Dermatol. 103: 6S-12S

Austin, S. J., Fujimoto, W., Marvin, K. W., Vollberg, T. M., Lorand, L. and Jetten, A. M. (1996) Cloning and regulation of cornifin beta, a new member of the cornifin/spr family. Suppression by retinoic acid receptor-selective retinoids. J. Biol. Chem. 271: 3737-3742

Baden, H. P., Hooker, P. A., Kubilus, J. and Tarascio, A. (1980) Sulfatase activity of keratinizing tissues in X-linked ichthyosis. Pediatr. Res 14: 1347-1348

Bale, S. J., Russell, L. J., Lee, M. L., Compton, J. G., and DiGiovanna, J. J. (1996) Congenital recessive ichthyosis unlinked to loci for epidermal transglutaminases. J. Invest. Dermatol. 107: 808-811

Brody, I. (1969) The modified plasma membranes of the transition and horny cells in normal human epidermis as revealed by electron microscopy. Acta Derm. Venereol . 49: 128-138

Candi, E., Melino, G., Pei, G., Tarcsa, E., Marekov, L. N. and Steinert, P. M. (1995) Bacterially-expressed human loricrin: Biochemical, structural and transglutaminase substrate properties of the major epidermal cornified cell envelope structural protein. $\mathrm{J}$. Biol. Chem. 270: 26382-26390

Candi, E., Melino, G., Lahm, A., Ceci, R., Rossi, A., Kim, I. G., Ciani, B. and Steinert, P. M. (1998a) Transglutaminase 1 mutations in lamellar ichthyosis. Loss of activity due to failure of activation by proteolytic pro-cessing. J. Biol. Chem. 273: 13693-13702

Candi, E., Tarcsa, E., DiGiovanna, J. J., Compton, J. G., Elias, P. M., Marekov, L. N. and Steinert, P. M. (1998b) A highly conserved lysine residue on the head domain of type II keratins is essential for the attach-ment of keratin intermediate filaments to the cornified cell envelope through isopeptide crosslinking by transglutaminases. Proc. Natl. Acad. Sci. USA 95: 2067-2072

Candi, E., Tarcsa, E., Kartasova, T., Idler, W. W., Marekov, L. N. and Steinert, P. M. (1999) Biochemical and transglutaminase substrate pro-perties of the small proline rich 1 family of cornified cell envelope proteins: integration with loricrin. J. Biol. Chem. 274: 7226-7237

Clement, S., Trejo-Skalli, A. V., Gu, L., Velasco, P. T., Lorand, L. and Goldman, R. D. (1998) J. Invest. Dermatol. 109: 778-782

Cline, P. R. and Rice, R. H. (1983) Modulation of involucrin and envelope competence in human keratinocytes by hydrocortisone, retinyl acetate, and growth arrest. Cancer Res. 43: 3203-3207
Crish, J. F., Howard, J. M., Zaim, T. M., Murthy, S. and Eckert, R. L. (1993) Tissuespecific and differentiation-appropriate expression of the human involucrin gene in transgenic mice: an abnormal epidermal phenotype. Differentiation 53: 191-200

Crish, J. F., Zaim, T. M. and Eckert, R. L. (1998) The distal regulatory region of the human involucrin promoter is required for expression in epidermis. J. Biol. Chem . 273: 3046030465

Dale, B. A., Holbrook, K. A. and Steinert, P. M. (1978). Assembly of stratum corneum basic protein and keratin filaments in macrofibrils. Nature 276: 729-731

De Laurenzi, V., Rogers, G. R., Hamrock, D. J., Marekov, L. N., Steinert, P. M., Compton, J. G., Marova, N. G. and Rizzo, W. B. (1996) Sjogren-Larsson syndrome is caused by mutations in the fatty aldehyde dehydro-genase gene. Nature Genet. 12: $52-$ 57

De Laurenzi, V., Rogers, G. R., Tarcsa, E., Carney, G., Marekov, L., Bale, S. J., Compton, J. G., Markova, N. G., Steinert, P. M. and Rizzo, W. B. (1997) SjogrenLarsson syndrome is caused by a common mutation in northern European and Swedish patients.J. Invest. Dermatol. 109: 79-83

de Viragh, P. A., Huber, M. and Hohl, D. (1994) Involucrin mRNA is more abundant in human hair follicles than in normal epidermis. J. Invest. Dermatol. 103: 815-819

de Viragh, P. A., Scharer, L., Bundmann, D. and Roop, D. R. (1997) Loricrin deficient mice: upregulation of other cell envelope precursors rescues the neonatal defect but fails to restore epidermal barrier function. J. Invest. Dermatol. 108: 555 [abstract]

DiSepio, D., Jones, A., Longley, M. A., Bundman, D., Rothnagel, J. A. and Roop, D. R. (1995) The proximal promoter of the mouse loricrin gene contains a functional AP-1 element and directs keratinocyte-specific but not differentiation- specific expression. $J$. Biol. Chem. 270: 10792-10799

Djian, P., Delhomme, B. and Green, H. (1995) Origin of the polymorphism of the involucrin gene in Asians. Am. J. Hum. Genet. 56: 1367-1372

Dlugosz, A. A. and Yuspa, S. H. (1993) Coordinate changes in gene ex-pression which mark the spinous to granular cell transition in epidermis are regulated by protein kinase C. J. Cell Biol. 120: 217-225

Dlugosz, A. A. and Yuspa, S. H. (1994) Protein kinase C regulates kera-tinocyte transglutaminase (TGK) gene expression in cultured primary mouse epidermal keratinocytes induced to terminally differentiate by calcium. J. Invest. Dermatol. 102: $409-414$

Downing, D. T. (1992) Lipid and protein structures in the permeability barrier of mammalian epidermis. J. Lipid Res. 33: 301-313

Downing, D. T., Stewart, M. E., Wertz, P. W. and Strauss, J. S. (1993) Lipids of the epidermis and sebaceous glands. In Dermatology in General Medicine (T. B. Fitzpatrick, ed.), pp. 210-22, McGraw-Hill, Inc., New York

Eckert, R. L. and Green, H. (1986) Structure and evolution of the human involucrin gene. Cell 46: 583-589

Eckert, R. L., Yaffe, M. B., Crish, J. F., Murthy, S., Rorke, E. A. and Welter, J. F. (1993) Involucrin - structure and role in envelope assembly. J. Invest. Dermatol. 100: 613-617

Eckert, R. L., Crish, J. F. and Robinson, N. A. (1997) The epidermal kera-tinocyte as a model for the study of gene regulation and cell differentiation. Physiol Rev. 77: 397-424

Elias, P. M. (1996) Skin lipids. J. Dermatol. 23: 756-758

Engelkamp, D., Schafer, B. W., Mattei, M. G., Erne, P. and Heizmann, C. W. (1993) Six S100 genes are clustered on human chromosome 1q21: identification of two genes coding for the two previously unreported calcium-binding proteins $\mathrm{S} 100 \mathrm{D}$ and $\mathrm{S} 100 \mathrm{E}$. Proc. Natl. Acad. Sci. USA 90: 6547-6551

Fartasch, M. (1997) Epidermal barrier in disorders of the skin. Microsc. Res. Tech. 38: $361-372$

Fischer D. F., Gibbs, S., van de Putte, P. and Backendorf, C. (1996) Inter-dependent transcription control elements regulate the expression of the SPRR2A gene during 
keratinocyte terminal differentiation. Mol. Cell Biol. 16: 5365-5374

Floyd, E. E. and Jetten, A. M. (1989) Regulation of type I (epidermal) transglutaminase mRNA levels during squamous differentiation: down regulation by retinoids. Mol. Cell Biol. 9: 4846-4851

Folk, J. E. and Finlayson, J. S. (1977) The epsilon-(gamma-glutamyl)lysine crosslink and the catalytic role of transglutaminases. Adv. Protein Chem. 31: 1-133

Friedman, Z. (1986) Essential fatty acid consideration at birth in the pre-mature neonate and the specific requirement for preformed prostaglandin precursors in the infant. Progr. Lipid Res. 25: 355-364

Fuchs, E., Yang, Y., Dowling, J., Yu, Q.-C. and Guo, L. (1997) Intermediate filament cytoarchitecture and BPAG1: a gene encoding two different types of intermediate filament linker proteins. In Cytoskeletal-Membrane Inter-actions and Signal Transduction (P. Cowin and M. W. Klymowsky, eds.), pp. 167-181, Landes Bioscience, Austin, TX

Fujimoto, W., Marvin, K. W., George, M. D., Celli, G., Darwiche, N., De Luca, L.M. and Jetten, A. M. (1993) Expression of cornifin in squamous differentiating epithelial tissues, including psoriatic and retinoic acid-treated skin. J. Invest. Dermatol. 101: 268-274

Gan, S.-Q., Idler, W. W., McBride, O. W., Markova, N. and Steinert, P. M. (1990). The structure, organization and polymorphisms of the human profilaggrin gene. Biochemistry 29: $9432-9440$

Garrod, D., Chidgey, M. and North, A. (1996) Desmosomes: differentiation, development, dynamics and disease. Curr. Opin. Cell Biol. 8: 670-678

Gibbs, R. C. and Frank, S. B. (1966) Keratoma hereditaria mutilans (Vohwinkel). Differentiating features of conditions with constriction of digits. Arch. Dermatol. 94: 619625

Gibbs, S., Lohman, F., Teubel, W., van de Putte, P. and Backendorf, C. (1990) Characterization of the human spr2 promoter: induction after UV irradiation or TPA treatment and regulation during differentiation of cultured primary keratinocytes. Nucleic Acids Res. 18: 4401-4407

Gibbs, S., Fijneman, R., Wiegant, J., van Kessel, A. G., van De Putte, P. and Backendorf, C. (1993) Molecular characterization and evolution of the SPRR family of keratinocyte differentiation markers encoding small proline-rich proteins. Genomics 16 : $630-637$

Greco, M. A., Lorand, L., Lane, W. S., Baden, H.P., Parameswaran, K. N. and Kvedar, J.C. (1995) The pancornulins: a group of small proline rich-related cornified envelope precursors with bifunctional capabilities in iso-peptide bond formation. J. Invest. Dermatol. 104: 204-210

Green, H. and Djian, P. (1992) Consecutive actions of different gene-altering mechanisms in the evolution of involucrin. Mol. Biol. Evol. 9: 977-1017

Green, K. J., Parry, D. A., Steinert, P. M., Virata, M. L., Wagner, R. M., Angst, B. D. and Nilles, L. A. (1990) Structure of the human desmoplakins. Implications for function in the desmosomal plaque. J. Biol. Chem. 265: 11406-11407

Green K K. J and Jones, J. C. (1996) Desmosomes and hemidesmosomes: structure and function of molecular components. FASEB J. 10: 871-881

Gross, M. and Folk, J. E. (1974) Activity of guinea pig liver transglutaminase toward ester analogs of amide substrates. J. Biol. Chem. 249: 3021-3025

Hashimoto, K. (1969) Cellular envelopes of keratinized cells of the human epidermis. Arch. Clin. Exp. Derm. 235: 374-385

Hennies, H. C., Kuster, W., Wiebe, V., Krebsova, A., and Reis, A. (1998) Genotype/phenotype correlation in autosomal recessive lamellar ichthyosis. Am. J. Hum. Genet. 62: 1052-1061

Hohl, D. (1990) The cornified cell envelope. Dermatologica 180: 201-211

Hohl, D., Mehrel, T., Lichti, U., Turner, M.L., Roop, D. R. and Steinert, P. M. (1991a) Characterization of human loricrin. Structure and function of a newclass of epidermal cell envelope proteins. J. Biol. Chem. 266: 6626-6636
Hohl, D., Lichti, U., Breitkreutz, D., Steinert, P. M. and Roop, D. R. (1991b) Transcription of the human loricrin gene in vitro is induced by calcium and cell density and suppressed by retinoic acid. J. Invest. Dermatol. 96: 414-418

Hohl, D., de Viragh, P. A., Amiguet-Barras, F., Gibbs, S., Backendorf, C. and Huber, M. (1995) The small proline-rich proteins constitute a multigene family of differentially regulated cornified cell envelope precursor proteins. J. Invest. Dermatol. 104: 902-909

Hohl, D., Aeschlimann, D. and Huber, M. (1998) In vitro and rapid in situ transglutaminase assays for congenital ichthyoses--a comparative study. J. Invest. Dermatol. 110: 268-271

Holbrook, K. A. and Wolff, K. (1993) The structure and development of the skin. In Dermatology in General Medicine (T. B. Fitzpatrick, ed.), pp. 97-145, McGraw-Hill, New York

Huber, M., Rettler, I., Bernasconi, K., Frenk, E., Lavrijsen, S. P., Ponec, M., Bon, A., Lautenschlager, S., Schordaret, D. F. and Hohl, D. (1995a) Mutations of keratinocyte transglutaminase in lamellar ichthyosis. Science 267: 525-528

Huber, M., Rettler, I., Bernasconi, K., Wyss, M. and Hohl, D. (1995b) Lamellar ichthyosis is genetically heterogeneous-cases with normal kera-tinocyte transglutaminase. $J$. Invest. Dermatol. 105: 653-654

Huber, M., Yee, V. C., Burri, N., Vikerfors, E., Lavrijsen, A. P., Paller, A. S. and Hohl, D. (1997) Consequences of seven novel mutations on the expression and structure of keratinocyte transglutaminase. J. Biol. Chem. 272: 21018-21026

Ishida-Yamamoto, A., Hohl, D., Roop, D. R., lizuka, H. and Eady, R. A. (1993) Loricrin immunoreactivity in human skin: localization to specific granules (L-granules) in acrosyringia. Arch. Dermatol. Res. 285: 491-498

Ishida-Yamamoto, A. and lizuka, H. (1995) Differences in involucrin immunolabeling within cornified cell envelopes in normal and psoriatic epidermis. J. Invest. Dermatol. 104: $391-395$

Ishida-Yamamoto, A., Eady, R. A., Watt, F. M., Roop, D. R., Hohl, D. and lizuka, H. (1996) Immunoelectron microscopic analysis of cornified cell envelope formation in normal and psoriatic epidermis. J. Histochem. Cytochem. 44: 167-175

Ishida-Yamamoto, A., McGrath, J. A., Lam, H., lizuka, H., Friedman, R. A. and Christiano, A. M. (1997) The molecular pathology of progressive symmetric erythrokeratoderma: a frameshift mutation in the loricrin gene and perturbations in the cornified cell envelope. Am. J. Hum. Genet. 61: 581-589

Ishida-Yamamoto, A., Takahashi, H. and lizuka, H. (1998) Loricrin and human skin diseases: molecular basis of loricrin keratodermas. Histo. Histopathol. 13: 819-826

Jansen, G. A., Ofman, R., Ferdinandusse, S., ljst, L., Muijsers, A. O. and Skjeldal, O. H. (1997) Refsum disease is caused by mutations in the phytanoyl-CoA hydroxylase gene. Nature Genet. 17: 190-193

Jarnik, M., Simon, M. N. and Steven, A. C. (1998) Cornified cell envelope assembly: a model based on electron miscriscopic deteminations of thickness and projected density. J. Cell Sci. 111: 1051-1060

Jarvinen, M., Rinne, A. and Hopsu-Havu, V. K. (1987) Human cystatins in normal and diseased tissues - a review. Acta Histochem. 82: 5-18

Kartasova, T. and van de Putte, P. (1988) Isolation, characterization, and UV-stimulated expression of two families of genes encoding polypeptides of related structure in human epidermal keratinocytes. Mol. Cell Biol. 8: 2195-2203

Kartasova, T., van Muijen, G.N., van Pelt-Heerschap, H. and van de Putte, P. (1988a) Novel protein in human epidermal keratinocytes: regulation of expression during differentiation. Mol. Cell Biol. 8: 2204-2210

Kartasova, T., Ponec, M. and van de Putte, P. (1988b) Induction of proteins and mRNAs after UV irradiation of human epidermal keratinocytes. Exp. Cell Res. 174: 421-432

Kartasova, T., Darwiche, N., Kohno, Y., Koizumi, H., Osada, S., Lichti, U., Steinert, P. M. and Kuroki, T. (1996) Sequence and expression patterns of mouse SPR1: Correlation of expression with epithelial function. J. Invest. Dermatol. 106: 294-304 
Kawabe, S., Ikuta, T., Ohba, M., Chida, K., Ueda, E., Yamanishi, K. and Kuroki, T. (1998) Cholesterol sulfate activates transcription of the trans-glutaminase 1 gene in normal human keratinocytes. J. Invest. Dermatol. 111: 1098-1102

Kim, H.-C., Lewis, M. S., Gorman, J. J., Park, S.-C., Girard, J. E., Folk, J. E. and Chung, S.-I. (1990) Protransglutaminase E from guinea pig skin. Isolation and partial characterization. J. Biol. Chem. 265: 21971-21978

Kim, H. C., Idler, W. W., Kim, I. G., Han, J. H., Chung, S.-I. and Steinert, P. M. (1991) The complete amino acid sequence of the human transglu-taminase $\mathrm{K}$ enzyme deduced from the nucleic acid sequences of cDNA clones. J. Biol. Chem. 266: 536-539

Kim, I.-G., McBride, O. W., Wang, M., Kim, S.-Y., Idler, W. W. and Steinert, P. M. (1992) Structure and organization of the human transglutaminase 1 (TGM1) gene. J. Biol. Chem. 267: 7710-7717

Kim, I.-G., Gorman, J. J., Park, S.-C., Chung, S.-I. and Steinert, P. M. (1993) The deduced sequence of the novel protransglutaminase $\mathrm{E}$ (TGase3) of human and mouse. J. Biol. Chem. 268: 12682-12690

Kim, S.-Y., Kim, I. G., Chung, S.-I. and Steinert, P. M. (1994) The structure of the transglutaminase 1 enzyme. Deletion cloning reveals domains that regulate its specific activity and substrate specificity. J. Biol. Chem. 269: 27979-27986

Kim, S.-Y., Chung, S.-I., Yoneda, K. and Steinert, P. M. (1995a) Expression of transglutaminase 1 in human epidermis. J. Invest. Dermatol. 104: 211-217

Kim, S.-Y., Chung, S.-I. and Steinert, P. M. (1995b) Highly active soluble processed forms of the transglutaminase 1 enzyme in epidermal kera-tinocytes. J. Biol. Chem. 270: $18026-18035$

Kimonis, V., DiGiovanna, J. J., Yang, J.-M., Dolye, S. Z. Bale, S. J. and Compton, J. G. (1994) A mutation in the V1 end domain of keratin 1 in non-epidermolytic palmar-plantar keratoderma. J. Invest. Dermatol. 103: 764-769

Korge, B. P., Ishida-Yamamoto, A., Punter, C., Dopping-Hepenstal, P. J., lizuka, H. and Stephenson, A. (1997) Loricrin mutation in Vohwinkel's keratoderma is unique to the variant with ichthyosis. J. Invest. Dermatol. 109: 604-610

Kouklis, P. D., Hutton, E. and Fuchs, E. (1994) Making a connection: direct binding between keratin intermediate filaments and desmosomal proteins. J. Cell Biol. 127: 10491060

Kubilus, J., Tarascio, A. J. and Baden, H. P. (1979) Steroid-sulfatase deficiency in sexlinked ichthyosis. Am. J. Hum. Genet. 31: 50-53

Lam, H., McGrath, J. A., Griffiths, W. A. D., Shimizu, H., Duke, E. E., Goldsmith, L. A. and Christiano, A. M. (1997) Genetic Heterogeneity in Mutilating Palmoplantar Keratodermas with Pseudoainhum. J. Invest. Dermatol. 108: 647

Landmann, L. (1980) Lamellar granules in mammalian, avian, and reptilian epidermis. J. Ultrastruct. Res. 72: 245-263

Landmann, L. (1986) Epidermal permeability barrier: transformation of lamellar granuledisks into intercellular sheets by a membrane-fusion process, a freeze- fracture study. $J$. Invest. Dermatol. 87: 202-209

Lee, J.-H., Jang, S.-I., Yang, J.-M., Markova, N. G. and Steinert, P. M. (1996) The proxima promoter of the human transglutaminase 3 gene. Stratified squamous epithelial-specific expression in cultured cells is mediated by binding of Sp1 and ets transcription factors to a proximal promoter element. J. Biol. Chem. 271: 4561-4568

Liemann, S. and Lewit-Bentley, A. (1995) Annexins: a novel family of calcium-and membrane-binding proteins in search of a function. Structure 3: 233-237

Liew, F. M. and Yamanishi, K. (1992) Regulation of transglutaminase 1 gene expression by 12-0-tetradecanoylphorbol-13-acetate, dexamethasone, and retinoic acid in cultured human keratinocytes. Exp. Cell Res. 202: 310-315

Lopez-Bayghen, E., Vega, A., Cadena, A., Granados, S. E., Jave, L. F., Gariglio, P. and Alvarez-Salas, L. M. (1996) Transcriptional analysis of the 5'-noncoding region of the human involucrin gene. J. Biol. Chem 271: 512-520

Lorand, L. and Conrad, S. M. (1984) Transglutaminases. Mol. Cell Bio-chem. 58:9-35
Mack, J. W. , Steven, A. C. and Steinert, P. M. (1993). Mechanism of interaction of filaggrin with intermediate filaments: the ionic zipper hypo-thesis. J. Mol. Biol. 232: 50-

Madison, K. C., Swartzendruber, D. C., Wertz, P. W. and Downing, D. T. (1988) Lamellar granule extrusion and stratum corneum intercellular lamellae in murine keratinocyte cultures. J. Invest. Dermatol. 90: 110-116

Mailliard, W. S., Haigler, H. T. and Schlaepfer, D. D. (1996) Calcium-depen-dent binding of S100C to the N-terminal domain of annexin I. J. Biol. Chem. 271: 719-725

Marekov, L. N. and Steinert, P. M. (1998) Ceramides are bound to structural proteins of the human foreskin epidermal cornified cell envelope. J. Biol. Chem. 273: 17763-17770

Mariniello, L., Qin, Q., Jessen, B. A. and Rice, R. H. (1995) Keratinocyte transglutaminase promoter analysis. Identification of a functional response element. $\mathrm{J}$. Biol. Chem. 270: 31358-31363

Markova, N., Chipev, C. C., Marekov, L., Idler, W. W. and Steinert, P. M. (1993). Profilaggrin is a major epidermal calcium binding protein. Mol. Cell. Biol.13:613-625

Martinet, N., Beninati, S., Nigra, T. P. and Folk, J. E. (1990) N1N8-bis (gammaglutamyl)spermidine cross-linking in epidermal-cell envelopes. Comparison of cross-link levels in normal and psoriatic cell envelopes. Biochem. J. 271: 305-308

Marvin, K. W., George, M. D., Fujimoto, W., Saunders, N. A., Bernacki, S. H. and Jetten, A. M. (1992) Cornifin, a cross-linked envelope precursorin keratinocytes that is down-regulated by retinoids. Proc. Natt. Acad. Sci. USA 89: 11026-11030

Matsuki, M., Yamashita, F., Ishida-Yamamoto, A., Yamada, K., Kinoshita, C., Fushiki, S. Ueda, E., Morishima, Y., Tabata, K., Yasuno, H., Hashida, M., lizuka, H., Ikawa, M., Okabe, M., Kondoh, G., Kinoshita, T., Takeda, J. and Yamanishi, K. (1998) Defective stratum corneum and early neonatal death in mice lacking the gene for transglutaminase 1 (keratinocyte transglutaminase). Proc. Natl. Acad. Sci. USA 95: 1044-1049

McKinley-Grant, L. G., Idler, W. W., Bernstein, I.A., Parry, D. A. D., Cannizzaro, L., Croce, C. M., Huebner, K., Lessin, S. R. and Steinert, P. M. (1989). Characterization of a cDNA clone encoding human filaggrin and localization of the gene to chromosome region 1q21. Proc. Natl. Acad. Sci. USA 86: 4848-4852

Mehrel, T., Hohl, D., Rothnagel, J. A., Longley, M. A., Bundman, D., Cheng, C., Steinert, P. M. and Roop, D. R. (1990) Identification of a major keratinocyte cell envelope protein, loricrin. Cell 61: 1103-1112

Michel, S., Schmidt, R., Robinson, S. M., Shroot, B. and Reichert, U. (1987) Identification and subcellular distribution of cornified envelope precursor proteins in the transformed human keratinocyte line SV-K14. J. Invest. Dermatol. 88: 301-305

Michel, S., Bernerd, F., Jetten, A. M., Floyd, E. E., Shroot, B. and Reichert, U. (1992) Expression of keratinocyte transglutamine mRNA revealed by in situ hybridization. $J$. Invest. Dermatol. 98: 364-368

Mischke, D., Korge, B. P., Marenholz, I., Volz, A. and Ziegler, A. (1996) Genes encoding structural proteins of epidermal cornification and $S 100$ calcium-binding proteins form a gene complex ("epidermal differentiation complex") on human chromosome 1q21. J. Invest. Dermatol. 106: 989-992

Molhuizen, H. O., Alkemade, H. A., Zeeuwen, P. L., de Jongh, G. J., Wieringa, B. and Schalkwijk, J. (1993) SKALP/elafin: an elastase inhibitor from cultured human keratinocytes. Purification, cDNA sequence, and evidence for transglutaminase crosslinking. J. Biol. Chem. 268: 12028-12032

Moog-Lutz, C., Bouillet, P., Regnier, C. H., Tomasetto, C., Mattei, M. G. and Chenard, M. P. (1995) Comparative expression of the psoriasin (S100A7) and S100C genes in breast carcinoma and co-localization to human chromosome 1q21-q22. Int. J. Cancer 63: 297303

Moore, K. G. and Sartorelli, A. C. (1992) Annexin I and involucrin are cross-linked by particulate transglutaminase into the cornified cell envelope of squamous cell carcinoma Y1. Exp. Cell Res. 200: 186-195 
Morgan, R. O. and Fernandez, M. P. (1997) Annexin gene structures and molecular evolutionary genetics. Cell Mol. Life Sci. 53: 508-515

Murthy, S., Crish, J. F., Zaim, T. M. and Eckert, R. L. (1993) A dual role for involucrin in the epidermis-ultrastructural localization in epidermis and hair follicle in humans and transgenic mice. J. Struct Biol. 111: 68-76

Negi, M., Colbert, M. C. and Goldsmith, L. A. (1985) High-molecular-weighthuman epidermal transglutaminase. J. Invest. Dermatol. 85: 75-78

Nemes, Z., Marekov, L. N. and Steinert, P. M. (1999) Involucrin cross-linking by transglutaminase 1: binding to membranes directs residue specificity. J. Biol. Chem 274: in the press

Nonomura, K., Yamanishi, K., Yasuno, H., Nara, K. and Hirose, S. (1994) Up-regulation of elafin/SKALP gene expression in psoriatic epidermis. J. Invest. Dermatol. 103: 88-91

Parmentier, L., Blanchet-Bardon, C., Nguyen, S., Prud'homme, J. F., Dubertret, L. and Weissenbach, J. (1995) Autosomal recessive lamellar ichthyosis: identification of a new mutation in transglutaminase 1 and evidence for genetic heterogeneity. Hum. Mol. Genet. 4: 1391-1395

Parry, D. A. D. and Steinert, P. M. (1995). The Structure and Function of Intermediate Filaments. E. Landis Publishing Company, Austin, TX

Petit, E., Huber, M., Rochat, A., Bodemer, C., Teillac-Hamel, D. and Muh, J. P. (1997) Three novel point mutations in the keratinocyte transglutaminase (TGK) gene in lamellar ichthyosis: significance for mutant transcript level, TGK immunodetection and activity. Eur. J. Hum. Genet. 5: 218-228

Pfundt, R., van Ruissen, F., van Vlijmen-Willems, I. M., Alkemade, H. A., Zeeuwen, P. L and Jap, P. H. (1996) Constitutive and inducible expression of SKALP/elafin provides antielastase defense in human epithelia. J. Clin. Invest. 98: 1389-1399

Phillips, M. A., Qin, Q., Mehrpouyan, M. and Rice, R. H. (1993) Keratinocyte transglutaminase membrane anchorage: analysis of site- directed mutants. Biochemistry 32: 11057-11063

Polakowska, R. R. and Goldsmith, L. A. (1991) The cell envelope and transglutaminases. In Biochemistry, Physiology and Molecular Biology of the Skin (L. A. Goldsmith, ed.), pp. 168-201, Oxford University Press, New York, Oxford

Presland, R. B., Haydock, P. V., Fleckman, P., Nirunsuksiri, W. and Dale, B. A. (1992) Characterization of the human epidermal profilaggrin gene. Genomic organization and identification of an S-100-like calcium binding domain at the amino terminus. J. Biol. Chem. 267: 23772-2378

Presland, R. B., Kimball, J. R., Kautsky, M. B., Lewis, S. P., Lo, C. Y. and Dale, B. A. (1997) Evidence for specific proteolytic cleavage of the $\mathrm{N}$-terminal domain of human profilaggrin during epidermal differentiation. J. Invest. Dermatol. 108: 170-178

Raghunath, M., Hennies, H. C., Velten, F., Wiebe, V., Steinert, P. M., Reis, A. and Traupe, $H$. (1998) A novel in situ method for the detection of deficient transglutaminase activity in the skin. Arch. Dermatol, in the press

Rawlings, N. D. and Barrett, A. J. (1990) Evolution of proteins of the cys-tatin superfamily. J. Mol. Evol. 30: 60-71

Reichert, U., Michel, S. and Schmidt, R. (1993) The cornified envelope: a key structure of terminally differentiating keratinocytes. In Molecular biology of the Skin. The Keratinocyte. (M. Darmon and M. Bloomenberg, eds.), pp. 107-150, Academic Press, San Diego

Ricardo Martinez, I., Jr. and Peters, A. (1971) Membrane-coating granules and membrane modifications in keratinizing epithelia. Am. J. Anat. 130: 93-119

Rice, R. H. and Green, H. (1979) Presence in human epithelial cells of a soluble protein precursor of the cross-linked envelope: activation of cross-linking by calcium ions. Cell 18: $681-694$

Rice, R. H., Rong, X.-H. and Chakravarty, R. (1990) Proteolytic release of keratinocyte transglutaminase. Biochem. J. 265: 351-357

Richards, S., Scott, I. R., Harding, C. R., Liddell, J. E., Powell, G. M. and Curtis, C. G.
(1988) Evidence for filaggrin as a component of the cell envelope of the newborn rat. Biochem. J. 253: 153-160

Robinson, N. A., LaCelle, P. T. and Eckert, R. L. (1996) Involucrin is a covalently crosslinked constituent of highly purified epidermal corneocytes: evidence for a common pattern of involucrin crosslinking in vivo and in vitro. J. Invest. Dermatol. 107: 101-107

Robinson, N. A., Lapic, S., Welter, J. F. and Eckert, R. L. (1997) S100A11, S100A10, annexin I, desmosomal proteins, small proline-rich proteins, plasminogen activator inhibitor-2, and involucrin are components of the cornified envelope of cultured human epidermal keratinocytes. J. Biol. Chem. 272: 12035-12046

Robinson, N. A. and Eckert, R. L. (1998) Identification of transglutaminase-reactive residues in S100A11. J. Biol. Chem. 273: 2721-2728

Rossi, A., Jang, S. I., Ceci, R., Steinert, P. M. and Markova, N. G. (1998) Effect of AP1 transcription factors on the regulation of transcription in normal human epidermal keratinocytes. J. Invest. Dermatol. 110: 34-40

Ruhrberg, C., Hajibagheri, M. A., Simon, M., Dooley, T. P. and Watt, F. M. (1996) Envoplakin, a novel precursor of the cornified envelope that has homology to desmoplakin. J. Cell Biol. 134: 715-729

Ruhrberg, C., Hajibagheri, M. A., Parry, D. A. and Watt, F. M. (1997) Peri-plakin, a novel component of cornified envelopes and desmosomes that belongs to the plakin family and forms complexes with envoplakin.J. Cell Biol. 139: 1835-1849

Russell, L. J., DiGiovanna, J. J., Rogers, G. R., Steinert, P. M., Hashem, N., Compton, J. G. and Bale, S. J. (1995) Mutations in the gene for trans-glutaminase 1 in autosomal recessive lamellar ichthyosis. Nature Genet. 9: 279-283

Saheki, T., Ito, F., Hagiwara, H., Saito, Y., Kuroki, J., Tachibana, S. and Hirose, S. (1992) Primary structure of the human elafin precursor pre-proelafin deduced from the nucleotide sequence of its gene and the presence of unique repetitive sequences in the prosegment. Biochem. Biophys. Res. Commun. 185: 240-245

Sak, M. W., Fischer, D. F., de Meijer, E., van de Putte, P. and backendorf, C. (1998) Ap1 and ets transcription factors regulate the expression of the human SPRR1A keratinocyte terminal differentiation marker. J. Biol. Chem. 273: 24683-24692

Sallenave, J. M. and Silva, A. (1993) Characterization and gene sequence of the precursor of elafin, an elastase-specific inhibitor in bronchial secre-tions. Am. J. Respir. Cell. Mol. Biol. 8: 439-445

Schalkwijk, J., de Roo, C. and de Jongh, G. J. (1991) Skin-derived anti-leukoproteinase (SKALP), an elastase inhibitor from human keratinocytes. Purification and biochemical properties. Biochim. Biophys. Acta 1096: 148-154

Schalkwijk, J., van Vlijmen, I. M., Alkemade, J. A. and de Jongh, G. J. (1993) Immunohistochemical localization of SKALP/elafin in psoriatic epidermis. J. Invest. Dermatol. 100: 390-393

Schroeder, W. T., Thacher, S. M., Stewart-Galetka, S., Annarella, M., Chema, D., Siciliano, M. J. (1992) Type I keratinocyte transglutaminase: expression in human skin and psoriasis. J. Invest. Dermatol. 99: 27-34

Schurer, N. Y. and Elias, P. M. (1991) The biochemistry and function of stratum corneum lipids. In Skin Lipids. Advances in Skin Lipid Research. (P. M. Elias, ed.), pp. 27-56, Academic Press, San Diego

Seemann, J., Weber, K. and Gerke, V. (1996) Structural requirements for annexin IS100C complex-formation. Biochem. J. 319: 123-129

Shapiro, L. J., Weiss, R., Buxman, M. M., Vidgoff, J., Dimond, R. L., Roller, J. A. and Wells, R. S. (1978) Enzymatic basis of X-linked ichthyosis. Lancet 2: 756-757

Shibuya, K., Kaji, H., Itoh, T., Ohyama, Y., Tsujikami, A. and Tate, S. (1995) Human cystatin $A$ is inactivated by engineered truncation. The NH2-terminal region of the cysteine proteinase inhibitor is essential for expression of its inhibitory activity. Biochemistry 34 : 12185-12192

Simon, M. and Green, H. (1984) Participation of membrane-associated proteins in the formation of the cross-linked envelope of the keratinocyte. Cell 36: 827-834 
Simon, M., Phillips, M. and Green, H. (1991) Polymorphism due to variable number of repeats in the human involucrin gene. Genomics 9: 576-580

Simon, M. (1994) The epidermal cornified envelope and its precursors. In The Keratinocyte Handbook, (I. M. Leigh, E. B. Lane, and F. M. Watt, eds.), pp. 275-292, Cambridge University Press, Cambridge

Simon, M., Haftek, M., Sebbag, M., Montezin, M., Girbal-Neuhauser, E., Schmitt, D. and Serre, G. (1996) Evidence that filaggrin is a component of cornified cell envelopes in human plantar epidermis. Biochem. J. 317: 173-177

Song, H.-J., Poy, G., Darwiche, N., Lichti, U., Kuroki, T., Steinert, P. M. and Kartasova, T. (1999) Mouse SPR2 genes: a clustered family of genes showing differential expression in epithelial tissues. Genomics in the press

Steinberg, D. S. (1978) Phytanic acid storage disease: Refsum's syndrome. In The Metabolic Basis of Inherited Disease. (J. B. Stanbury, J. B. Wyngaarden and D. S. Frederickson, eds.), pp. 688-691, McGraw-Hill, New York

Steinert, P. M. (1995) A model for the hierarchical structure of the cornified cell envelope. Cell Death Different. 2: 33-40

Steinert, P. M. (1996). Intermediate filaments in health and disease. Exp. Molec. Med. 29: $55-63$

Steinert, P. M., Mack, J. W., Korge, B. P., Gan, S. Q., Haynes, S. R. and Steven, A. C. (1991) Glycine loops in proteins: their occurrence in certain intermediate filament chains, loricrins and single-stranded RNA binding proteins. Int. J. Biol. Macromol. 13: 130-139

Steinert, P. M. and Marekov, L. N. (1995) The proteins elafin, filaggrin, keratin intermediate filaments, loricrin, and small proline-rich proteins 1 and 2 are isodipeptide cross-linked components of the human epidermal cornified cell envelope. J Biol. Chem. 270: $17702-17711$

Steinert, P. M., Kim, S.-Y., Chung, S.-I. and Marekov, L. N. (1996a) The transglutaminase 1 enzyme is variably acylated by myristate and palmitate during differentiation in epidermal keratinocytes. J. Biol. Chem. 271: 26242-26250

Steinert, P. M., Chung, S.-I. and Kim, S.-Y. (1996b) Inactive zymogen and highly active proteolytically processed membrane-bound forms of the transglutaminase 1 enzyme in human epidermal keratinocytes. Biochem. Biophys. Res. Commun. 221: 101-106

Steinert, P. M. and Marekov, L. N. (1997) Direct evidence that involucrin is a major early isopeptide cross-linked component of the keratinocyte cornified cell envelope. J. Biol. Chem. 272: 2021-2030

Steinert, P. M., Candi, E., Kartasova, T. and Marekov, L. N. (1998a) Small proline-rich proteins are cross-bridging proteins in the cornified cell envelopes of stratified squamous epithelia. J. Struct. Biol. 122: 76-85

Steinert, P. M., Kartasova, T. and Marekov, L. N. (1998b) Biochemical evidence that small proline-rich proteins and trichohyalin function in epithelia by modulation of the biomechanical properties of their cornified cell envelopes. J. Biol. Chem. 273: 1175811769

Steven, A. C., Bisher, M. E., Roop, D. R. and Steinert, P. M. (1990) Bio-synthetic pathways of filaggrin and loricrin - two major proteins expressed by terminally differentiated epidermal keratinocytes. J. Struct. Biol. 104: 150-162

Steven, A. C. and Steinert, P. M. (1994) Protein composition of cornified cell envelopes of epidermal keratinocytes. J. Cell Sci. 107: 693-700

Su, M. J., Bikle, D. D., Mancianti, M. L. and Pillai, S. (1994) 1,25-Dihydro-xyvitamin D3 potentiates the keratinocyte response to calcium. J. Biol. Chem. 269: 14723-14729

Swartzendruber, D. C., Wertz, P. W., Madison, K. C. and Downing, D. T. (1987) Evidence that the corneocyte has a chemically bound lipid envelope. J. Invest. Dermatol. 88: $709-713$

Swartzendruber, D. C., Wertz, P. W., Kitko, D. J., Madison, K. C. and Downing, D. T. (1989) Molecular models of the intercellular lipid lamellae in mammalian stratum corneum. J. Invest. Dermatol. 92: 251-257

Swartzendruber, D. C., Manganaro, A., Madison, K. C., Kremer, M., Wertz, P. W. Squier,
C. A. (1995) Organization of the intercellular spaces of porcine epidermal and palatal stratum corneum: a quantitative study employing ruthenium tetroxide. Cell Tissue Res . 279: $271-276$

Takahashi, M., Tezuka, T. and Katunuma, N. (1992) Phosphorylated cystatin alpha is a natural substrate of epidermal transglutaminase for formation of skin cornified envelope. FEBS Lett. 308: 79-82

Takahashi, H. and lizuka, H. (1993) Analysis of the $5^{\prime}$-upstream promoter region of human involucrin gene: activation by 12-0-tetradecanoylphorbol-13-acetate. J. Invest. Dermatol. 100: 10-15

Takahashi, M., Tezuka, T., Kakegawa, H. and Katunuma, N. (1994) Linkage between phosphorylated cystatin alpha and filaggrin by epidermal trans-glutaminase as a mode of cornified envelope and inhibition of cathepsin $L$ activity by cornified envelope and the conjugated cystatin alpha. FEBS Lett. 340: 173-176

Takahashi, H., Kinouchi, M., Wuepper, K. D. and lizuka, H. (1997) Cloning of human keratolinin CDNA: keratolinin is identical with a cysteine pro-teinase inhibitor, cystatin $A$, and is regulated by $\mathrm{Ca}^{2+}$, TPA, and cAMP. J. Invest. Dermatol. 108: 843-847

Tarcsa, E., Marekov, L. N., Andreoli, J. M., Idler, W. W., Candi, E., Chung, S.-I. and Steinert, P.M. (1997) The fate of trichohyalin: sequential post-translational modifications by peptidylarginine deiminase and transglu-taminases. J. Biol. Chem. 272: 2789327901

Tarcsa, E., Candi, E., Kartasova, T., Idler, W. W., Marekov, L. N. and Steinert, P. M. (1998) Structural and transglutaminase substrate properties of the small proline rich 2 family of cornified cell envelope proteins. J. Biol. Chem. 273: 23297-23303

Traupe, H. (1989) The Ichthyoses: A Guide to Clinical Diagnosis, Genetic Counseling and Therapy. Springer-Verlag, Heidelberg

Tseng, H. and Green, H. (1988) Remodeling of the involucrin gene during primate evolution. Cell 54: 491-496

Virata, M. L., Wagner, R. M., Parry, D. A. and Green, K. J. (1992) Molecular structure of the human desmoplakin I and II amino terminus. Proc. Natl. Acad. Sci. USA 89: 544548

Vohwinkel, H. (1929) Keratoma hereditaria mutilans. Arch. Dermatol. Syphilol. 158: $354-$ 364

Volz, A., Korge, B. P., Compton, J. G., Ziegler, A., Steinert, P. M. and Mischke, D. (1993) Physical mapping of a functional cluster of epidermal differentiation genes on chromosome 1q21. Genomics 18: 92-99

Wang, M., Kim, I.-G., Steinert, P. M. and McBride, O. W. (1994) Assign-ment of the human transglutaminase 2 (TGM2) and transglutaminase 3 (TGM3) genes to chromosome 20q11.2. Genomics 23: 721-722

Watt, F. M. and Green, H. (1981) Involucrin synthesis is correlated with cell size in human epidermal cultures. J. Cell Biol. 90: 738-742

Welter, J. F., Crish, J. F., Agarwal, C. and Eckert, R. L. (1995) Fos-related antigen(Fra1), junB, and junD activate human involucrin promoter trans-cription by binding to proximal and distal AP1 sites to mediate phorbol ester effects on promoter activity. J. Biol. Chem. 270: 12614-12622

Welter, J. F., Gali, H., Crish, J. F. and Eckert, R. L. (1996) Regulation of human involucrin promoter activity by POU domain proteins. J. Biol. Chem. 271: 14727-14733

Wertz, P. W. and Downing, D. T. (1987a) Covalently bound omega-hydroxy-acylsphingosine in the stratum corneum. Biochim. Biophys. Acta 917: 108-111

Wertz, P. W., Swartzendruber, D. C., Abraham, W., Madison, K. C. and Downing, D. T. (1987b) Essential fatty acids and epidermal integrity. Arch. Dermatol. 123: 1381-1384

Wertz, P. W., Swartzendruber, D. C., Kitko, D. J., Madison, K. C. and Downing, D. T. (1989a) The role of the corneocyte lipid envelopes in cohesion of the stratum corneum. J. Invest. Dermatol. 93: 169-172

Wertz, P.W., Madison, K. C. and Downing, D. T. (1989b) Covalently bound lipids of human stratum corneum. J. Invest. Dermatol. 92: 109-111 
Wertz, P. W. and Downing, D. T. (1991) Epidermal lipids. In Physiology, Biochemistry and Molecular Biology of the Skin. (L. A. Goldsmith, ed.), Oxford University Press, Oxford. pp. 205-236

Wertz, P. W. (1997) Integral lipids of hair and stratum corneum. Experientia 78: 227-237

Wiedow, O., Schroder, J. M., Gregory, H., Young, J. A. and Christophers, E. (1990) Elafin: an elastase-specific inhibitor of human skin. Purification, characterization, and complete amino acid sequence.J. Biol. Chem. 265: 14791-14795

Wiedow, O., Ludemann, J., Utecht, B. and Christophers, E. (1993) Inhibition of proteinase 3 activity by peptides derived from human epidermis. Adv. Exp. Med. Biol. 336: 61-64

Williams, M. L. and Elias, P. M. (1987) Genetically transmitted, generalized disorders of cornification. Dermatology Clinics 5: 155-178

Williams, M. L. (1992) Epidermal lipids and scaling diseases of the skin. Sem. Dermatol. 11: $169-175$

Yaar, M., Eller, M. S., Bhawan, J., Harkness, D. D., DiBenedetto, P. J. and Gilchrest, B. A. (1995) In vivo and in vitro SPRR1 gene expression in normal and malignant keratinocytes. Exp. Cell Res. 217: 217-226

Yaffe, M. B., Beegen, H. and Eckert, R. L. (1992) Biophysical characteri-zation of involucrin reveals a molecule ideally suited to function as an intermolecular cross-bridge of the keratinocyte cornified envelope.J. Biol. Chem. 267: 12233-12238

Yaffe, M. B., Murthy, S. and Eckert, R. L. (1993) Evidence that involucrin is a covalently linked constituent of highly purified cultured keratinocyte cornified envelopes. J. Invest. Dermatol. 100: 3-9

Yamada, H., Takamori, K. and Ogawa, H. (1987) Localization and some properties of skin sulfhydryl oxidase. Arch. Dermatol. Res. 279: 194-197

Yamada, K., Yamanishi, K., Kakizuka, A., Kibe, Y., Doi, H. and Yasuno, H. (1994) Transcriptional regulation of human transglutaminase 1 gene by signaling systems of protein kinase C, RAR/RXR and Jun/Fos in keratinocytes. Biochem. Mol. Biol. Int. 34: 827-836

Yamanishi, K., Inazawa, J., Liew, F. M., Nonomura, K., Ariyama, T. and Yasuno, H. (1992) Structure of the gene for human transglutaminase 1. J. Biol. Chem. 267: 1785817863

Yoneda, K., Hohl, D., McBride, O. W., Wang, M., Cehrs, K. U., Idler, W. W. and Steinert, P. M. (1992) The human loricrin gene. J. Biol. Chem. 267: 18060-18066

Yoneda, K. and Steinert, P. M. (1993). The over-expression of loricrin in transgenic mice produces a normal phenotype. Proc. Natl. Acad. Sci. USA 90: 10754-10758

Younus, J. and Gilchrest, B. A. (1992) Modulation of mRNA levels during human keratinocyte differentiation. J. Cell Physiol. 152: 232-239

Zahn, H. and Gattner, H.-G. (1997) Hair sulfur amino acid analysis. In Formation and Structure of Human Hair (P. Jolles, H. Zahn and H. Hocker, eds.), pp. 239-258, Birkhauser Verlag, Basel

Zettergren, J. G., Peterson, L. L. and Wuepper, K. D. (1984) Keratolinin: the soluble substrate of epidermal transglutaminase from human and bovine tissue. Proc. Natl. Acad. Sci. USA. 81: 238-242

Zettersten, E., Man, M. Q., Sato, J., Denda, M., Farrell, A., Ghadially, R., Williams, M. L., Feingold, K. R., and Elias, P. M. (1998) Recessive X-linked ichthyosis: role of cholesterol-sulfate accumulation in the barrier abnormality. J. Invest. Dermatol. 111: 784-790

Zhang, B., Healy, P. J. Zhao, Y., Crabb, D. W. and Harris, R. A. (1990) Premature translation termination of the pre-E1 alpha subunit of the branched chain alpha-ketoacid dehydrogenase as a cause of maple syrup urine disease in Polled Hereford calves. $\mathrm{J}$. Biol. Chem. 265: 2425-2430 